Check for updates

Cite this: RSC Adv., 2019, 9, 41475

\title{
Copper chloride as a conversion-type positive electrode for rechargeable aluminum batteries
}

\author{
Masanobu Chiku, (D) Takeshi Kunisawa, Eiji Higuchi and Hiroshi Inoue
}

Copper chloride $\left(\mathrm{CuCl}_{2}\right)$ was investigated for the first time as conversion-type positive electrode material in a rechargeable Al battery. The electrode was reversibly charged and discharged in an electrolyte solution of $\mathrm{AlCl}_{3}$, dipropylsulfone, and toluene (1:10:5 molar ratio). The initial discharge capacity was about $370 \mathrm{~mA} \mathrm{~h}\left(\mathrm{~g}-\mathrm{CuCl}_{2}\right)^{-1}$ at $0.028 \mathrm{C}$-rate $\left(11 \mathrm{~mA}\left(\mathrm{~g}-\mathrm{CuCl}_{2}\right)^{-1}\right)$, which was almost the same as the theoretical value $\left(399 \mathrm{~mA} \mathrm{~h}\left(\mathrm{~g}-\mathrm{CuCl}_{2}\right)^{-1}\right.$ ) and higher than that of insertion-type positive electrode materials as used in the rechargeable Al battery. Moreover, a two-stage discharge plateau voltage was observed at $1.5 \mathrm{~V}$ and $0.8 \mathrm{~V}$, which was higher than other conversion type positive electrodes for the aluminum rechargeable battery. The high discharge voltage realized a high energy density of 426 $\mathrm{mW} \mathrm{h}\left(\mathrm{g}-\mathrm{CuCl}_{2}\right)^{-1}$, which is the highest energy density compared with other conversion type positive electrodes. Two different strategies were implemented to increase the lifetime of the cell, namely, increasing the upper cut-off voltage and decreasing the particle size of $\mathrm{CuCl}_{2}$. The discharge capacity for the electrode at the second cycle was threefold that for a pristine $\mathrm{CuCl}_{2}$ electrode.

Received 5th November 2019 Accepted 26th November 2019

DOI: 10.1039/c9ra09158k

rsc.li/rsc-advances
Chevrel-phase $\mathrm{Mo}_{3} \mathrm{~S}_{4}$ positive electrode is used in the rechargeable $\mathrm{Al}$ battery, the cell voltage will be low. Guo et al. reported the $\mathrm{Al}$ battery with $\mathrm{Mo}_{3} \mathrm{~S}_{4}$ positive electrode, and it show two distinct plateaus at 0.55 and $0.37 \mathrm{~V}^{5}$

Vanadium oxides, which have a layered structure and insert cations between layers for maintaining charge balance, are also promising candidates for positive electrode active materials. So far, $\mathrm{V}_{2} \mathrm{O}_{5}$ nanowires ${ }^{6}$ and hydrothermally deposited $\mathrm{V}_{2} \mathrm{O}_{5}$ (ref. 7) and $\mathrm{VO}_{2}$ (ref. 8) have been investigated. We found that amorphous $\mathrm{V}_{2} \mathrm{O}_{5}$ could function as an active material for the positive electrode in a rechargeable $\mathrm{Al}$ battery. A maximum discharge capacity of about $200 \mathrm{~mA} \mathrm{~h}\left(\mathrm{~g}-\mathrm{V}_{2} \mathrm{O}_{5}\right)^{-1}$ at a rate of $0.025 \mathrm{C}$ was obtained. ${ }^{9}$ Amine and co-workers reported that a $\mathrm{V}_{2} \mathrm{O}_{5}$ electrode that was directly deposited onto a $\mathrm{Ni}$ current collector exhibited a maximum discharge capacity of $270 \mathrm{~mA} \mathrm{~h}\left(\mathrm{~g}-\mathrm{V}_{2} \mathrm{O}_{5}\right)^{-1},{ }^{10}$ which was higher than that of any other oxide based positive electrode active material for the rechargeable Al battery. However, the energy density was not sufficient for commercialization of the device.

To increase the capacity of rechargeable Al batteries, a new approach is necessary. ${ }^{\mathbf{1 1 - 1 3}}$ One solution is to devise new positive electrode active materials that have different charge/discharge mechanisms. Transition metal chlorides do not have vacant sites to accommodate $\mathrm{Li}^{+}$, but they can function as positive electrode active materials under the following reversible conversion reaction: ${ }^{14}$

$$
\mathrm{MCl}_{n}+n \mathrm{Li}^{+}+n \mathrm{e}^{-} \rightleftarrows \mathrm{M}+n \mathrm{LiCl}(\mathrm{M}: \text { transition metal) }
$$

Transition metal ions are reduced to metal during discharging, and $\mathrm{Cl}^{-}$ions react with $\mathrm{Li}^{+}$ions in the electrolyte to form the ionic 
compound LiCl. ${ }^{14}$ Thus, dynamic phase changes between $\mathrm{MCl}_{n}$ and LiCl occur reversibly during the charge/discharge processes, and these processes are different from those for insertion-type positive electrodes. The conversion-type electrode has increased the capacity of $\mathrm{LIBs}^{10}$ and may offer a possibility for improving the positive electrode properties of the rechargeable $\mathrm{Al}$ battery.

Donahue et al. reported the use of $\mathrm{FeCl}_{3}$ as the first conversion-type positive electrode active material for the rechargeable $\mathrm{Al}$ battery. ${ }^{15}$ Uchimoto et al. reported $\mathrm{FeS}_{2}$ as conversion type positive electrode material for rechargeable $\mathrm{Al}$ battery; however, this battery showed relatively low voltage below $1.2 \mathrm{~V}$ and the operation temperature was at $55{ }^{\circ} \mathrm{C} .{ }^{16} \mathrm{Co} / \mathrm{Ni} / \mathrm{Cu}-$ based metal-sulfur positive electrodes were also investigated, and $\mathrm{Ni}_{3} \mathrm{~S}_{2}$ show $0.8 \mathrm{~V}$ plateau voltage and $350 \mathrm{~mA} \mathrm{~h} \mathrm{~g}^{-1}$ discharge capacity. ${ }^{17-19} \mathrm{SnS}_{2}$ was also investigated as conversion type positive electrode material, and the discharge capacity reached $392 \mathrm{~mA} \mathrm{~h} \mathrm{~g}^{-1}$; however, its discharge voltage plateau was limited as $0.7 \mathrm{~V}^{20}$ In this study, we investigated three transition metal chlorides, namely, $\mathrm{CuCl}_{2}, \mathrm{CuCl}$, and $\mathrm{FeCl}_{2}$, as conversion-type positive electrode materials for the rechargeable $\mathrm{Al}$ battery to realize high voltage discharging over $1.5 \mathrm{~V}$ at $30{ }^{\circ} \mathrm{C}$.

\section{Experimental}

\subsection{Materials}

Dipropylsulfone (Tokyo Chemical Industry) and all other chemicals (Wako Pure Chemical) were used as received without any purification. Molybdenum plate was purchased from Nilaco Corporation. Ketjen black (KB, EC600JD) was purchased from Lion Corporation.

\subsection{Preparation of $\mathrm{FeCl}_{2}, \mathrm{CuCl}$, and $\mathrm{CuCl}_{2}$ pellet electrodes}

The $\mathrm{FeCl}_{2}, \mathrm{CuCl}$, and $\mathrm{CuCl}_{2}$ powders $(88 \% \mathrm{w} / \mathrm{w})$ were each mixed with $\mathrm{KB}(10 \% \mathrm{w} / \mathrm{w})$ and polytetrafluoroethylene $(2 \% \mathrm{w} / \mathrm{w})$ to be $20 \mathrm{mg}$ as total mass, followed by pressing at $290 \mathrm{MPa}$ for $3 \mathrm{~min}$ to form pellets $13 \mathrm{~mm}$ in diameter with $c a .200 \mu \mathrm{m}$ thickness.

The $\mathrm{CuCl}_{2}$ powder was treated by mechanical milling to reduce the particle size. The powder was put into a $45 \mathrm{~mL}$ zirconia pot containing seven zirconia balls $10 \mathrm{~mm}$ diameter. Mechanical milling was performed with a planetary ball-mill apparatus (Fritsch, Model Pulverisette 7). The milling speed was $157 \mathrm{rpm}$ and the milling times were $0.5,4$, and $12 \mathrm{~h}$.

\subsection{Electrochemical and spectroscopic characterization}

All electrochemical measurements were performed using a labbuilt glass cell. ${ }^{9}$ A mixture of aluminum chloride, dipropylsulfone $\left(\mathrm{DPSO}_{2}\right)$, and toluene (1: $10: 5$ molar ratio) served as the electrolyte solution. A Mo plate $(1.3 \mathrm{~cm} \times 1.3 \mathrm{~cm})$, which was used as the current collector, was immersed in conc. $\mathrm{HCl}$ for several seconds before use. An Al plate $(10 \mathrm{~mm}$ in diameter, $0.2 \mathrm{~mm}$ in thickness) was used as the counter and reference electrodes in all electrochemical experiments. A glass fiber filter (Advantec, Ltd.) was used as the separator. A test cell was
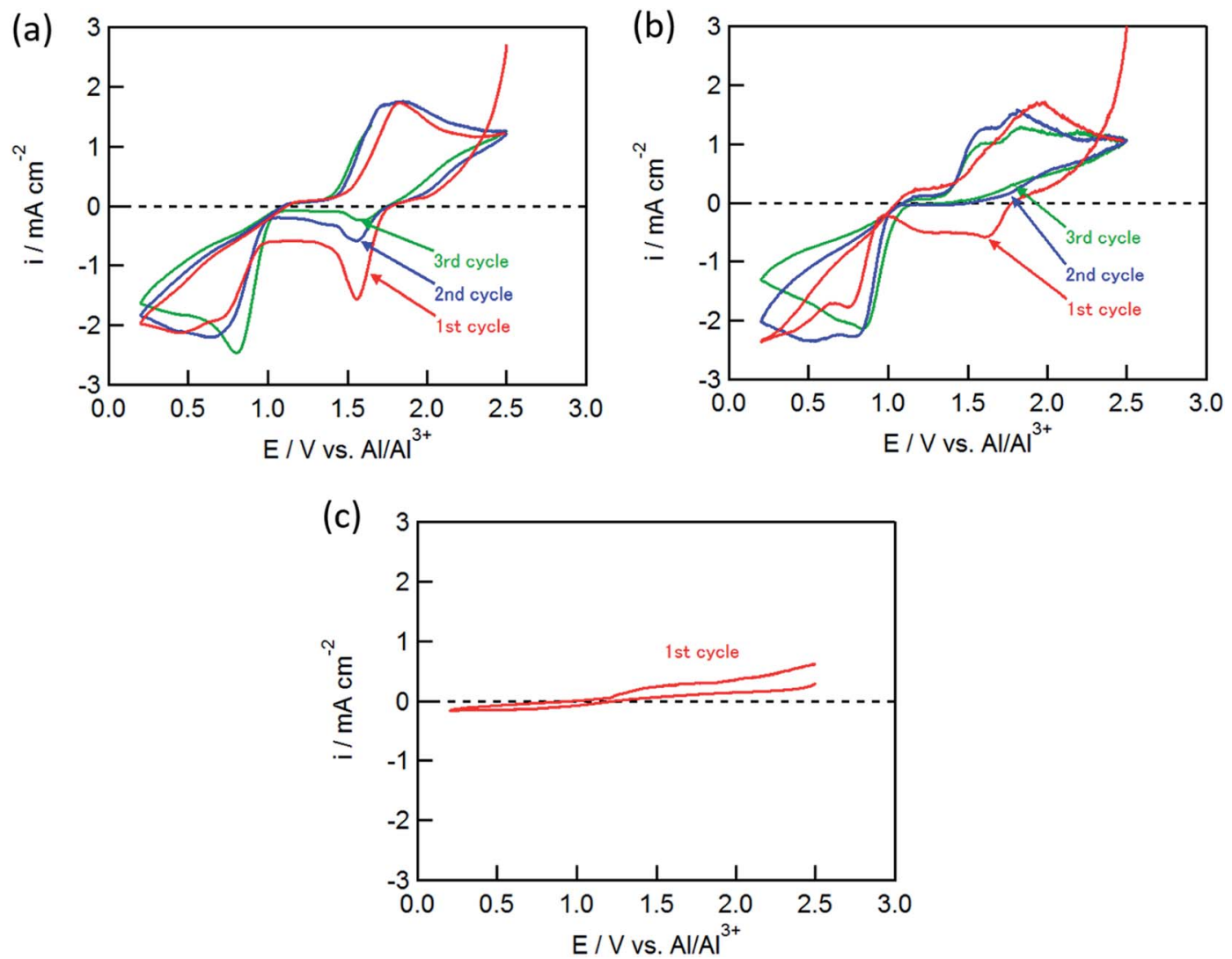

Fig. $1 \mathrm{CVs}$ of (a) $\mathrm{CuCl}_{2}$, (b) $\mathrm{CuCl}$, and (c) $\mathrm{FeCl}_{2}$ electrodes in $\mathrm{AlCl}_{3} / \mathrm{DPSO}_{2} /$ toluene solution. Sweep rate, $0.1 \mathrm{mV} \mathrm{s}^{-1}$. 
assembled in an Ar-filled glovebox. Cyclic voltammetry and charge/discharge tests were performed at $30{ }^{\circ} \mathrm{C}$ using an SI1287 potentiostat (Solartron) and an HJ1001SM8 charge/discharge system (Hokuto Denko), respectively. X-ray diffraction (XRD) spectra were measured by an X-ray diffractometer $(50 \mathrm{kV}, 30 \mathrm{~mA}$; XRD-6100, Shimadzu) equipped with a $\mathrm{Cu} \mathrm{K} \alpha$ source $(\lambda=0.1541$ $\mathrm{nm}$ ). Scanning electron microscope (SEM) images and energydispersive X-ray analysis (EDX) were performed with an S-4500 field-emission SEM (Hitachi) and EDAX system (Ametec), respectively.

\section{Results and discussion}

Fig. 1 shows the cyclic voltammograms (CVs) for the $\mathrm{CuCl}_{2}$, $\mathrm{CuCl}$, and $\mathrm{FeCl}_{2}$ pellet electrodes in the $\mathrm{AlCl}_{3} / \mathrm{DPSO}_{2} /$ toluene $(1: 10: 5)$ solution. As shown in Fig. 1(a), the $\mathrm{CuCl}_{2}$ electrode exhibited several redox peaks: cathodic peaks at around 0.6 and $1.6 \mathrm{~V}$, and an anodic peak at $1.8 \mathrm{~V}$. The cathodic peaks are attributable to the $\mathrm{Cu}^{2+} / \mathrm{Cu}^{+}$and $\mathrm{Cu}^{+} / \mathrm{Cu}$ couples at the higher and lower potentials, respectively. ${ }^{\mathbf{1 1}}$

Similar to eqn (1), the conversion reactions for the $\mathrm{CuCl}_{2}$ electrode are

$$
\begin{gathered}
\mathrm{Al}^{3+}+3 \mathrm{e}^{-}+3 \mathrm{Cu}(\mathrm{II}) \mathrm{Cl}_{2} \\
\mathrm{Al}^{3+}+3 \mathrm{e}^{-}+3 \mathrm{Cu}(\mathrm{I}) \mathrm{Cl}(\mathrm{I}) \mathrm{Cl}+\mathrm{AlCl}_{3} \\
\rightleftarrows 3 \mathrm{Cu}(0)+\mathrm{AlCl}_{3}
\end{gathered}
$$

The cathodic peak at $1.6 \mathrm{~V}$ gradually decreased with an increase in the number of cycles, whereas the cathodic peak around $0.6 \mathrm{~V}$ and the anodic peak at $1.8 \mathrm{~V}$ did not change, suggesting that the latter two peaks corresponded to the redox couple for $\mathrm{Cu}^{+} / \mathrm{Cu}$, and that the anodic reaction of $\mathrm{Cu}^{+}$to $\mathrm{Cu}^{2+}$ was not observed in this potential range. The $\mathrm{CuCl}$ electrode showed similar CVs to the $\mathrm{CuCl}_{2}$ electrode as shown in Fig. 1(b); however, the cathodic peak at $1.6 \mathrm{~V}$ was not observed in the second cycle, although the electrochemical reduction (eqn (2)) of the partially oxidized $\mathrm{CuCl}$ occurred to a small extent in the first cycle. In contrast, electrochemical reactions were not observed for the $\mathrm{FeCl}_{2}$ electrode (Fig. 1(c)), which was different from the results of Donahue et al. They used reticulated vitreous carbon (RVC) as the current collector; however, this proved deleterious because $\mathrm{AlCl}_{4}{ }^{-}$was inserted into carbon during the oxidation. ${ }^{21}$ The charge/discharge curve of the $\mathrm{FeCl}_{3}$ positive electrode largely agreed with that for a carbon positive electrode as reported by Dai and co-workers, ${ }^{21}$ suggesting that the positive electrode material was not $\mathrm{FeCl}_{3}$ but carbon itself. In this study, the Mo current collector was used as an alternative to the RVC current collector, so the insertion of $\mathrm{AlCl}_{4}{ }^{-}$did not occur in the present experiment, clearly indicating that carbon served as the positive electrode material and not $\mathrm{FeCl}_{2}$.

Fig. 2(a) and (b) show the charge/discharge curves of the $\mathrm{CuCl}_{2}$ and $\mathrm{CuCl}$ pellet positive electrodes. The initial discharge capacity
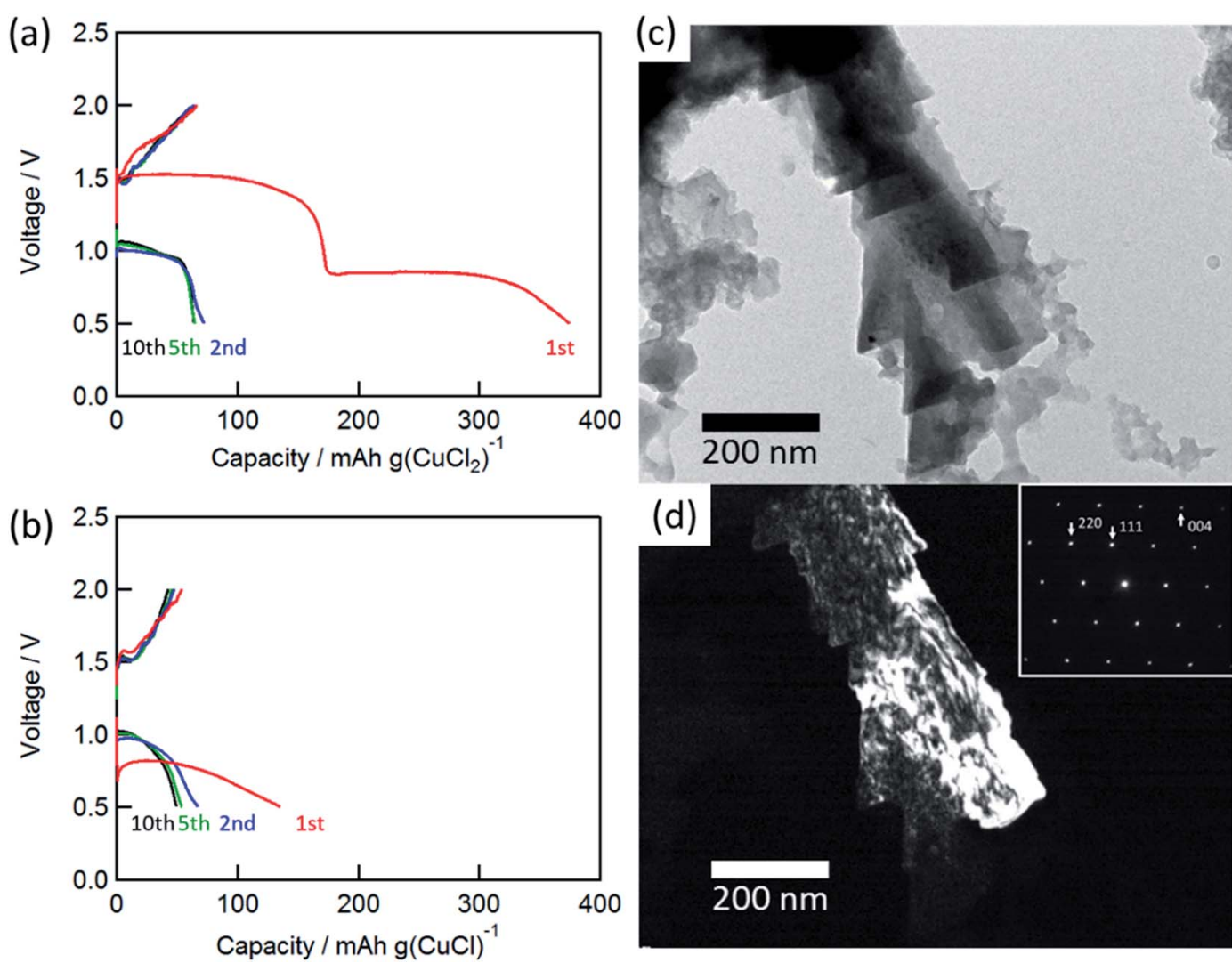

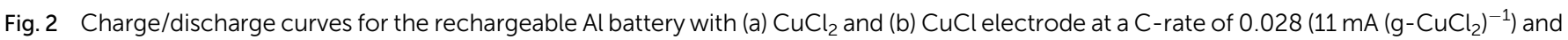
$0.043\left(17 \mathrm{~mA}(\mathrm{~g}-\mathrm{CuCl})^{-1}\right.$ ). TEM images: (c) bright-field image and (d) dark-field image of $\mathrm{CuCl}$ (111). Inset shows the SAED pattern of the charged electrode. 
for the $\mathrm{CuCl}_{2}$ electrode was about $370 \mathrm{~mA} \mathrm{~h}\left(\mathrm{~g}-\mathrm{CuCl}_{2}\right)^{-1}$, which was almost the same as the theoretical capacity $\left(399 \mathrm{~mA} \mathrm{~h}\left(\mathrm{~g}-\mathrm{CuCl}_{2}\right)^{-1}\right)$. The initial discharge curves had potential plateaus at 0.8 and $1.5 \mathrm{~V}$, and their capacities were similar to each other. Therefore, the twostep anodic reactions (eqn (2) and (3)) proceeded with an initial discharging at the $\mathrm{CuCl}_{2}$ electrode. The discharge curve of the $\mathrm{CuCl}$ electrode showed only one plateau at $0.8 \mathrm{~V}$, which can be attributed to eqn (3). The energy density was calculated as 425.5 $\mathrm{mW} \mathrm{h}\left(\mathrm{g}-\mathrm{CuCl}_{2}\right)^{-1}$ by multiplying the discharge voltage and discharge capacity. $\mathrm{SnS}_{2}$ positive electrode shows the discharge capacity as $392 \mathrm{~mA} \mathrm{~h} \mathrm{~g}^{-1}$; however, its discharge voltage was below $0.8 \mathrm{~V}$ and its energy density was $313.6 \mathrm{~mW} \mathrm{~h} \mathrm{~g}^{-1} .^{20}$ Other conversion type positive electrode materials show lower capacity and almost the same discharge voltage than $\mathrm{SnS}_{2} \cdot{ }^{17-19}$ Therefore our aluminum battery with $\mathrm{CuCl}_{2}$ electrode has the highest energy density comparing with other conversion type electrodes.

The charge and discharge capacities after initial discharging drastically decreased to below $70 \mathrm{~mA} \mathrm{~h}\left(\mathrm{~g}-\mathrm{CuCl}_{2}\right)^{-1}$, which could be attributed to the electro-elution of copper ions into the electrolyte solution. After the first discharge, the electrolyte solution was taken from the cell and dried, and then elemental analysis of the residue was performed by EDX. The elemental results were as follows: $\mathrm{Al} 54.22$ at\%, S 10.28 at\%, Cl 33.60 at\%, and $\mathrm{Cu} 1.90$ at\%, suggesting that a part of active material was dissolved into the solution. Fang et al. suggested the modified separator was effective to increase cyclability, and we considered the same type of separator may also be valid for the rechargeable aluminum battery with $\mathrm{CuCl}_{2}$ electrode. ${ }^{22}$ To understand the charge/discharge mechanisms, transmission electron microscopy (TEM) measurements were performed.

Fig. 2(c) and (d) show the bright-field and dark-field images for $\mathrm{CuCl}$ (111) and the selected-area electron diffraction (SAED) pattern of the charged electrode. The SAED pattern suggested that the discharged active material was $\mathrm{CuCl}$, and the $\mathrm{CuCl}$ crystal exhibited a complicated shape on the carbon substrate. Unfortunately, a clear TEM image for the discharged material was not obtained. This result suggested that the active material was converted to $\mathrm{CuCl}$ during the charge/discharge cycles.

To understand the charge/discharge mechanism better, the standard electrode potential for each redox reaction was calculated. The two oxidation reactions at the positive electrode and the $\mathrm{Al}$ electrodeposition reaction at the negative electrode are represented as follows:

Positive electrode:

$$
\begin{gathered}
\mathrm{Cu}+\mathrm{Cl}^{-} \rightarrow \mathrm{CuCl}+\mathrm{e}^{-} \quad E^{\circ}=0.108 \mathrm{~V} \text { vs. SHE } \\
\mathrm{CuCl}+\mathrm{Cl}^{-} \rightarrow \mathrm{CuCl}_{2}+\mathrm{e}^{-} \quad E^{\circ}=0.936 \mathrm{~V} \text { vs. SHE }
\end{gathered}
$$

Negative electrode:

$$
\mathrm{Al}^{3+}+3 \mathrm{e}^{-} \rightarrow \mathrm{Al} \quad E^{\circ}=-1.68 \mathrm{~V} \text { vs. SHE }
$$

The theoretical decomposition voltage $\left(E_{\mathrm{d}}^{\circ}\right)$ during the charging process was calculated as $1.78 \mathrm{~V}$ by eqn (4) and $2.61 \mathrm{~V}$ by eqn (5) from the difference in $E^{\circ}$ values between each positive electrode reaction and the negative electrode reaction in eqn (6).
These voltages were higher than the discharge plateau voltages of the $\mathrm{CuCl}_{2}$ and $\mathrm{CuCl}$ electrodes. This means that the discharge voltage was decreased by overvoltage and the production of $\mathrm{CuCl}_{2}$ can occur at charge voltages higher than $2.61 \mathrm{~V}$. Thus, we raised the upper limit of the cut-off voltage to improve the cycle performance of the $\mathrm{CuCl}_{2}$ pellet electrode.

Fig. 3(a) shows the CVs (third cycle) of the $\mathrm{CuCl}_{2}$ pellet electrode over a wide potential range (0-4 V) and a narrow potential range $(0-2.5 \mathrm{~V})$. In the $\mathrm{CV}$ with the narrow potential range, an oxidation peak at about $1.8 \mathrm{~V}$ and a broad reduction peak around 0.5-1.0 V were observed. In the CVs with the wide potential range, an additional broad oxidation peak was observed at $2.7 \mathrm{~V}$, suggesting that an upper limit of over $2.7 \mathrm{~V}$ is required in order to charge the $\mathrm{CuCl}_{2}$ positive electrode, probably according to eqn (5). This charge voltage agreed well with the calculated value of 2.61 V. Fig. 3(b) shows the charge/ discharge curves of the $\mathrm{CuCl}_{2}$ pellet electrode between 0.5 and $4.0 \mathrm{~V}$. The discharge capacities in the second and third cycles were 175 and $90 \mathrm{~mA} \mathrm{~h}\left(\mathrm{~g}-\mathrm{CuCl}_{2}\right)^{-1}$, respectively, which were higher than those in the second and third cycles, as the upper limit of the charge potential was $2.0 \mathrm{~V}$ (Fig. 2(a)). These findings suggest that charging the $\mathrm{CuCl}_{2}$ pellet electrode to the higher voltage was effective, but that the cyclability was insufficient.
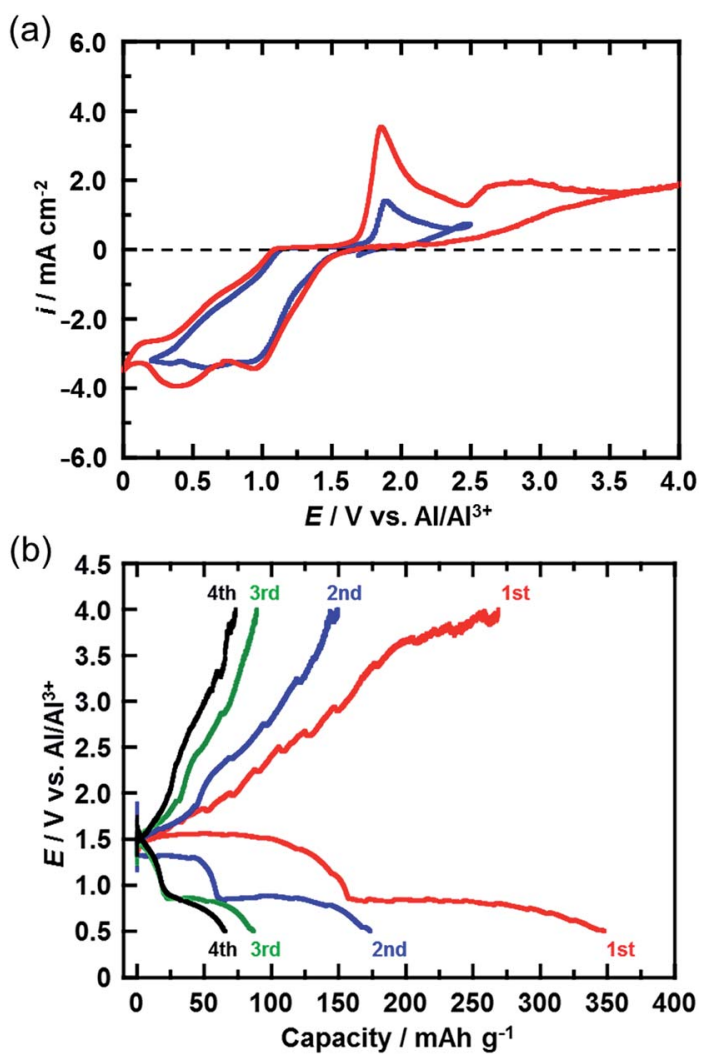

Fig. 3 (a) $\mathrm{CVs}$ (third cycle) of the $\mathrm{CuCl}_{2}$ electrode in $\mathrm{AlCl}_{3} / \mathrm{DPSO}_{2} /$ toluene solution for potential sweep ranges of $0-2.5 \mathrm{~V}$ and $0-4 \mathrm{~V}$. Sweep rate, $0.1 \mathrm{mV} \mathrm{s}^{-1}$. (b) Charge/discharge curves for the rechargeable $\mathrm{Al}$ battery with the $\mathrm{CuCl}_{2}$ electrode at a $\mathrm{C}$-rate of $0.028\left(11 \mathrm{~mA}\left(\mathrm{~g}-\mathrm{CuCl}_{2}\right)^{-1}\right)$. The cut-off voltage during charging was $4 \mathrm{~V}$. 
(a)

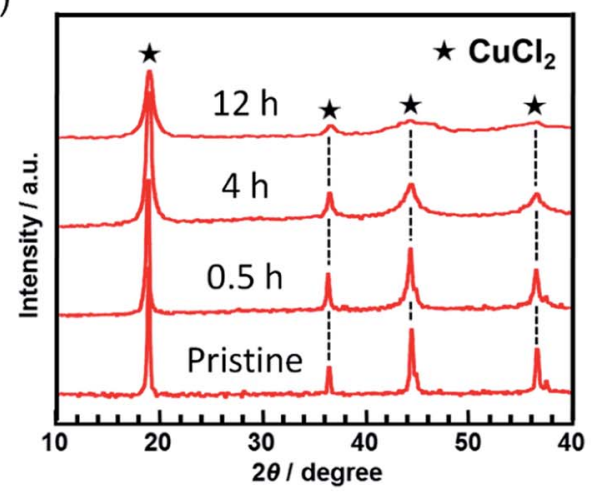

(b)

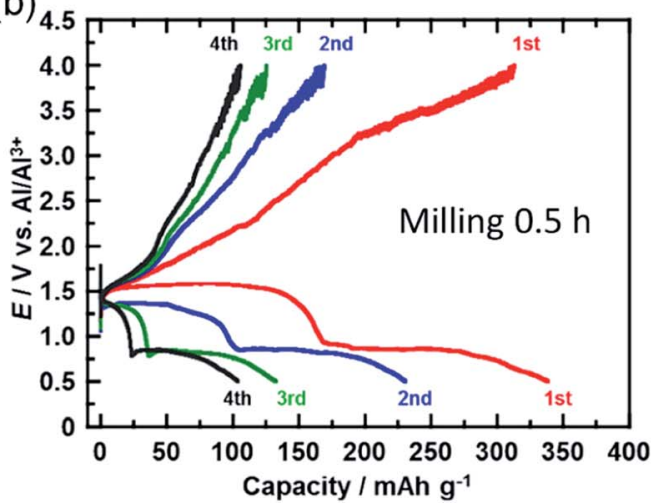

(c)

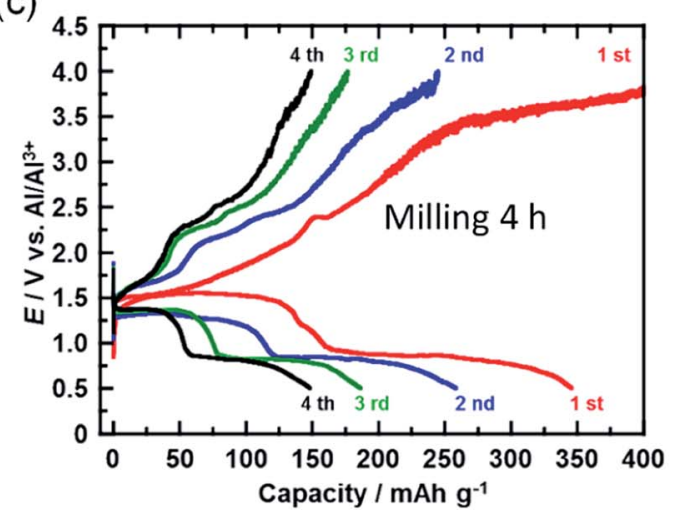

(d)

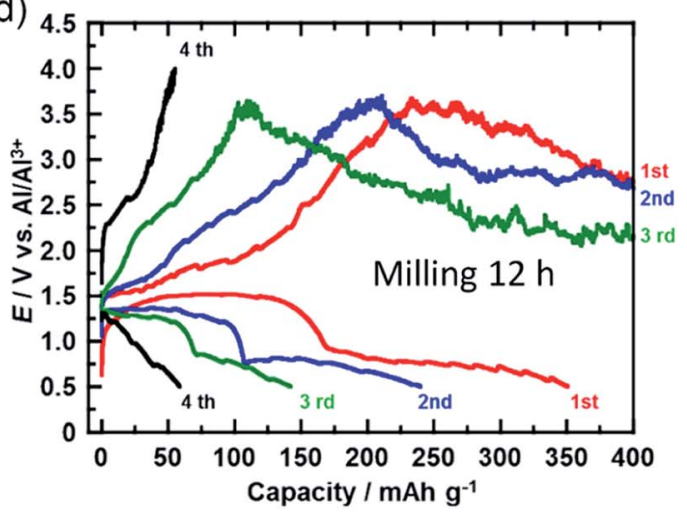

Fig. 4 (a) XRD patterns for $\mathrm{CuCl}_{2}$ powders ball-milled for different time periods. (b-d) Charge/discharge curves for the rechargeable Al batteries with ball-milled $\mathrm{CuCl}_{2}$ electrodes at a C-rate of $0.028\left(11 \mathrm{~mA}\left(\mathrm{~g}-\mathrm{CuCl}_{2}\right)^{-1}\right)$. Ball-milling times were (b) 0.5 , (c) 4, and (d) $12 \mathrm{~h}$.

In a further attempt to improve cyclability, the size of the $\mathrm{CuCl}_{2}$ particles in the prepared electrode was reduced. Fig. 4(a) shows the XRD spectra of the $\mathrm{CuCl}_{2}$ powders ball-milled for different time periods. The diffraction peak broadened as the milling time increased, suggesting that the size of the $\mathrm{CuCl}_{2}$ particles was reduced by ball-milling. $\mathrm{CuCl}_{2}$ powders ball-milled for $0.5,4$, and $12 \mathrm{~h}$ are referred to as $\mathrm{CuCl}_{2}[\mathrm{~m} 0.5], \mathrm{CuCl}_{2}[\mathrm{~m} 4]$ and $\mathrm{CuCl}_{2}[\mathrm{~m} 12]$, respectively.

The crystalline size of $\mathrm{CuCl}_{2}$ was calculated with the Scherrer equation;

$$
D=\frac{K \lambda}{B \cos \theta}
$$

where $D$ is the crystalline size (nm), $K$ is shape factor (0.9), $\lambda$ is the wavelength of the X-ray, $B$ is the full width at half maximum, $\theta$ is the Bragg angle. Each crystalline size was calculated as $24.0 \mathrm{~nm}$ (pristine), $18.0 \mathrm{~nm}\left(\mathrm{CuCl}_{2}[\mathrm{m0.5}]\right), 14.4 \mathrm{~nm}\left(\mathrm{CuCl}_{2}[\mathrm{~m} 4]\right)$, and $8.0 \mathrm{~nm}\left(\mathrm{CuCl}_{2}[\mathrm{~m} 12]\right)$, respectively.

Fig. $4(\mathrm{~b}-\mathrm{d})$ show the charge/discharge curves of the $\mathrm{CuCl}_{2}[\mathrm{~m} 0.5], \mathrm{CuCl}_{2}[\mathrm{~m} 4]$, and $\mathrm{CuCl}_{2}[\mathrm{~m} 12]$ pellet electrodes, respectively. The $\mathrm{CuCl}_{2}[\mathrm{~m} 0.5]$ and $\mathrm{CuCl}_{2}[\mathrm{~m} 4]$ electrodes showed better cyclability than the pristine $\mathrm{CuCl}_{2}$ electrode, and the $\mathrm{CuCl}_{2}[\mathrm{~m} 4]$ electrode performed the best of the three electrodes. The discharge capacity at the fifth cycle for the rechargeable Al battery with the $\mathrm{CuCl}_{2}[\mathrm{~m} 4]$ electrode was $150 \mathrm{~mA} \mathrm{~h}\left(\mathrm{~g}-\mathrm{CuCl}_{2}\right)^{-1}$, which was about threefold that for the pristine $\mathrm{CuCl}_{2}$ electrode. For the $\mathrm{CuCl}_{2}[\mathrm{~m} 12]$ electrode, the charge process was not terminated. As expected, $\mathrm{CuCl}_{2}[\mathrm{~m} 12]$ had the smallest particle size as evidenced by having the broadest diffraction peaks. The smaller the particle size, the larger the interfacial surface area for the conversion reaction, thus leading to better electrochemical reversibility. The charging voltage of the $\mathrm{CuCl}_{2}[\mathrm{~m} 12]$ electrode initially increased to $3.5 \mathrm{~V}$, and then decreased to $3.0 \mathrm{~V}$, suggesting that unfavorable processes occurred. The discharge capacity at the second cycle was $250 \mathrm{~mA} \mathrm{~h}\left(\mathrm{~g}-\mathrm{CuCl}_{2}\right)^{-1}$, indicating that the positive electrode was not seriously damaged. Decreasing the size of the $\mathrm{CuCl}_{2}$ particles increased the surface area of the active material of the positive electrode and may have accelerated the electrochemical decomposition of the electrolyte prior to the charge reactions of eqn (4) and (5), hence the cell voltage did not reach $4.0 \mathrm{~V}$. Based on these results, the rapid reduction of the discharge capacity of the $\mathrm{CuCl}_{2}$ electrode, as depicted in Fig. 2(b), might be attributable to the low cut-off voltage and the large particle size of the $\mathrm{CuCl}_{2}$ particles.

\section{Conclusion}

Three transition metal chloride salts were examined as potential candidates for the conversion-type positive electrode active materials for rechargeable $\mathrm{Al}$ batteries. The rechargeable $\mathrm{Al}$ battery with the $\mathrm{CuCl}_{2}$ and $\mathrm{CuCl}$ positive electrodes worked well. For the $\mathrm{CuCl}_{2}$ electrode, plateaus in electrode potential were observed around 0.8 and $1.5 \mathrm{~V}$ during the discharge process. The initial discharge capacity of the $\mathrm{CuCl}_{2}$ electrode was similar 
to its theoretical value of $370 \mathrm{~mA} \mathrm{~h}\left(\mathrm{~g}-\mathrm{CuCl}_{2}\right)^{-1}$ and energy density was $392 \mathrm{~mA} \mathrm{~h} \mathrm{~g}^{-1}$. This value is higher than that of other conversion-type positive electrode materials for the rechargeable Al battery. However, the discharge capacity at the second cycle rapidly decreased to less than $20 \%$ of the theoretical value. To improve the cyclability of the $\mathrm{CuCl}_{2}$ positive electrode, the upper cut-off voltage was increased to $4.0 \mathrm{~V}$ and the size of the $\mathrm{CuCl}_{2}$ particles was decreased by mechanical milling. Consequently, the discharge capacity at the fifth cycle for the electrode made with the $\mathrm{CuCl}_{2}$ powder that was ball-milled for $4 \mathrm{~h}$ was $150 \mathrm{~mA} \mathrm{~h}\left(\mathrm{~g}-\mathrm{CuCl}_{2}\right)^{-1}$, which is about threefold that for the pristine $\mathrm{CuCl}_{2}$ electrode.

\section{Conflicts of interest}

There are no conflicts to declare.

\section{Acknowledgements}

This work was supported by JSPS KAKENHI Grant Number $16 \mathrm{~K} 21288$.

\section{References}

1 J. F. M. Oudenhoven, L. Baggetto and P. H. L. Notten, Adv. Energy Mater., 2011, 1, 10-33.

2 J. Muldoon, C. B. Bucur and T. Gregory, Chem. Rev., 2014, 114, 11683-11720.

3 J. S. Lee, S. T. Kim, R. Cao, N. S. Choi, M. Liu, K. T. Lee and J. Cho, Adv. Energy Mater., 2011, 1, 34-50.

4 D. Aurbach, Z. Lu, A. Schechter, Y. Gofer, H. Gizbar, R. Turgeman, Y. Cohen, M. Moshkovich and E. Levi, Nature, 2000, 407, 724-727.

5 L. Geng, G. Lv, X. Xing and J. Guo, Chem. Mater., 2015, 27, 4926-4929.

6 N. Jayaprakash, S. K. Das and L. A. Archer, Chem. Commun., 2011, 47, 12610-12612.
7 H. Wang, Y. Bai, S. Chen, X. Luo, C. Wu, F. Wu, J. Lu and K. Amine, ACS Appl. Mater. Interfaces, 2015, 7, 80-84.

8 W. Wang, B. Jiang, W. Xiong, H. Sun, Z. Lin, L. Hu, J. Tu, J. Hou, H. Zhu and S. Jiao, Sci. Rep., 2013, 3, 3383.

9 M. Chiku, H. Takeda, S. Matsumura, E. Higuchi and H. Inoue, ACS Appl. Mater. Interfaces, 2015, 7, 24385-24389.

10 H. Wang, Y. Bai, S. Chen, X. Luo, C. Wu, F. Wu, J. Lu and K. Amine, ACS Appl. Mater. Interfaces, 2015, 7, 80-84.

11 Z. Yu, S. Jiao, S. Li, X. Chen, W.-L. Song, T. Teng, J. Tu, H.-S. Chen, G. Zhang and D.-N. Fang, Adv. Funct. Mater., 2019, 29, 1806799.

12 Z. Zhou, N. Li, Y. Yang, H. Chen, S. Jiao, W.-L. Song and D. Fang, Adv. Energy Mater., 2018, 8, 1801439.

13 G. Li, J. Tu, M. Wang and S. Jiao, J. Mater. Chem. A, 2019, 7, 8368-8375.

14 J. Zheng, M. Gu, J. Xiao, B. J. Polzin, P. Yan, X. Chen, C. Wang and J. Zhang, Electrochim. Acta, 2012, 68, 202-205.

15 F. M. Donahue, S. E. Mancini and L. Sionsen, J. Appl. Electrochem., 1992, 22, 230-234.

16 T. Mori, Y. Orikasa, K. Nakanishi, C. Kezheng, M. Hattori, T. Ohta and Y. Uchimoto, J. Power Sources, 2016, 313, 9-14.

17 Y. Hu, D. Ye, B. Luo, H. Hu, X. Zhu, S. Wang, L. Li, S. Peng and L. Wang, Adv. Mater., 2018, 30, 1703824.

18 S. Wang, S. Jiao, J. Wang, H. S. Chen, D. Tian, H. Lei and D. N. Fang, ACS Nano, 2017, 11, 469-477.

19 S. Wang, Z. Yu, J. Tu, J. Wang, D. Tian, Y. Liu and S. Jiao, Adv. Energy Mater., 2016, 6, 1600137.

20 Y. Hu, B. Luo, D. Ye, X. Zhu, M. Lyu and L. Wang, Adv. Mater., 2017, 29, 1606132.

21 M. C. Lin, M. Gong, B. Lu, Y. Wu, D. Y. Wang, M. Guan, M. Angell, C. Chen, J. Yang, B. J. Hwang and H. Dai, Nature, 2015, 520, 325-328.

22 X. Zhang, S. Jiao, J. Tu, W.-L. Song, X. Xiao, S. Li, M. Wang, H. Lei, D. Tian, H. Chen and D. Fang, Energy Environ. Sci., 2019, 12, 1918-1927. 